Original Research Paper

\title{
The Effect of Bacterial Enzyme-Based Feed Additives on the Productivity, Digestibility and Assimilation of Nutrients in Young Laying Hens
}

\author{
${ }^{1}$ Smolentsev Sergei Yur'evich, ${ }^{2}$ Rudakova Natalia Leonidovna, \\ ${ }^{2}$ Koryagina Anastasia Olegovna, ${ }^{2}$ Bulmakova Daria Sergeevna, ${ }^{2}$ Suleymanova Aliya Damirovna, \\ ${ }^{2}$ Mardanova Ayslu Mirkasimovna and ${ }^{2}$ Sharipova Margarita Rashidovna \\ ${ }^{1}$ Mari state University, Yoshkar-Ola, Russia, 424000, Russia \\ ${ }^{2}$ Kazan (Volga Region) Federal University, Kazan, Russia, 420008, Russia
}

\author{
Article history \\ Received: 05-09-2020 \\ Revised: 16-11-2020 \\ Accepted: $18-11-2020$ \\ Corresponding Author: \\ Rudakova Natalia Leonidovna \\ Kazan (Volga Region) Federal \\ University, Kazan, Russia, \\ 420008, Russia \\ Email: natalialrudakova@mail.ru
}

\begin{abstract}
The work aimed to study the effect of feed additives based on proteinase and phytase on the productivity, digestibility of nutrients and the development of laying hens up to 18 weeks of age. A total of 3601 -day-old Hisex Brown chickens were assigned to a completely randomized design composed of 3 diets with 4 replicates of 30 birds each. Dietary treatments were: (1) Control group: Basic diet with nutritional parameters consistent with recommended feeding standards, without enzymes additives, (2) experimental group A: Basic diet with the addition of proteinase at a concentration of $10 \mathrm{U} / \mathrm{kg}$, (3) experimental group B: Basic diet with the addition of phytase at a concentration of $1000 \mathrm{FTU} / \mathrm{kg}$. It has been shown that by adding microbial enzyme is increased digestibility of organic matter of diet of laying hens $(\mathrm{p}<0.05)$ : The use of proteinases and phytase had a favourable influence on the absorption of calcium, phosphorus and nitrogen. The addition of enzymes in the feed resulted in an increased in body weight and weight gain in absolute hens with a decrease in the total amount of feed consumed by birds $(\mathrm{p}<0.05)$. The inclusion of proteinase and phytase in the diet of laying hens increases the digestibility of nitrogen, phosphorus and calcium, leads to a decrease in the amount of feed consumed and also does not adversely affect histomorphological and biochemical blood parameters.
\end{abstract}

Keywords: Hisex Brown Laying Hens, Feed Additives, Proteinase, Phytase, Balance Experience, Digestibility

\section{Introduction}

The use of feed enzymes is an actively developing area in the nurturing of farm birds and has shown active growth over the past decade. The need for the use of enzymes is rooted in the development of new advanced technologies of modern poultry farming, the increased need for productive crosses and the importance of reducing the cost of the final product.

Enzymes play a key role in the digestion processes of animals. Their activity determines the dietary indicator referred to as digestibility, i.e., the degree of nutrient assimilation of the feed. An important indicator for the productivity of laying hens is egg production, which largely depends on the diet.
Balancing the contents of protein, amino acids, minerals and vitamins is essential for high productivity in this category of birds. The feed mixture for laying hens is based on grain containing an increased amount of poorly digestible phytates, which accommodate up to $80 \%$ of the total phosphorus content in the grain (Vieira et al., 2016).

Chickens remain deficient in phosphates from phytic acid due to the low activity of their intestinal phytases, thus the bulk of ingested phytates transits through the gastrointestinal tract of chickens unassimilated. The addition of inorganic phosphorus to the diet leads to the accumulation of excess phytin phosphorus in excreta, which in turn causes environmental pollution and eutrophication of water bodies (Abd El-Hack et al., 2018). 
To enhance the efficacy of grain-based compound feeds, phytases are added to the diet for phytate hydrolysis and the release of phosphates. Besides improving the phosphorus nutrition of animals, which cuts back its accumulation in droppings, the addition of phytases to feed increases the bioavailability of many minerals and proteins that would be otherwise bound to phytate (Dersjant-Li et al., 2015). Successful application of feed phytases in poultry farming has been reported for broilers, turkeys and geese (Abd El-Hack et al., 2018).

A positive effect of phytase addition on feed intake, digestibility of minerals and nutrients, egg production and weight, as well as eggshell quality has been established in laying hens (Hassanien and Sanaa, 2011; Kim et al., 2017).

In addition to phytases, proteinases, which ensure the most efficient use of the protein component of feed, are actively gaining popularity. It is crucial that proteinases do not cause self-proteolytic inactivation in the body, but synergize in their modus operandi with digestive proteases (Yuan et al., 2017; Jiang et al., 2020). Several studies have shown that supplementing poultry feed with proteinases improves growth indicators and amino acid digestibility (Dozier III et al., 2010; Angel et al., 2011; Lee et al., 2018; Mahmood et al., 2018; Siegert et al., 2019). Exogenous proteinases serve prophylactic purposes and reduce the level of undigested protein and thus, hampering colonization of intestines by pathogenic bacteria (Timbermont et al., 2010; Yan et al., 2017). Proteinases boost the number of probiotic species including Lactobacillus and decrease the population of pathogenic bacteria such as $C$. perfringens in the ileum of broiler chickens Ross 308 (Giannenas et al., 2017; Borda-Molina et al., 2019).

We studied the prospective application of histidine acid 3-phytase of Pantoea sp. 3.5.1 and subtilisin-like proteinase of B. pumilus $7 \mathrm{p}$ as dietary supplements for laying hens. An important aspect of the novelty of this work is that the producing strains were obtained from local soils and the bacterial enzymes were first isolated and described in detail in our laboratory. The MALDI-TOF method was used to establish primary structures of the enzymes. Genes of the corresponding proteins were cloned and the DNA of producer strains were sequenced (AN JHUD00000000; AN JMRT00000000.2) (Suleimanova et al., 2015a; 2015b; Mikhailova et al., 2009a).

For preliminary purification, a sufficient quantity of enzymes was obtained from media cultured with the microbial strains. The phytase of Pantoea sp. 3.5.1. was cloned in Pichia pastoris (Troshagina et al., 2018). Effective secretion by the yeast and glycosylation modification properties were noted for the enzyme. The obtained highly purified phytase $(80 \mathrm{kDa})$ was stable at a $\mathrm{pH}$ range of 2.0-5.0 with maximum activity at $\mathrm{pH} 3.0$ (authentic protein at $\mathrm{pH} 4.5$ ), which conforms to the acidic environment in the chicken stomach. For the recombinant phytase, the optimum temperature range was found to be from 37 to $50^{\circ} \mathrm{C}$. With an increased thermostability, the recombinant enzyme retained more than $95 \%$ activity at $70^{\circ} \mathrm{C}$, while the native enzyme lost more than $50 \%$ activity at $50^{\circ} \mathrm{C}$ (Suleimanova, in press). Increased thermal stability is an important factor in the production of food additives. The optimum temperature of the purified proteinase was $37^{\circ} \mathrm{C}$; for the purpose of diet supplementation, it is important that calcium ions at a final concentration of $5 \mathrm{mM}$ increase the temperature optimum of the enzyme to $50^{\circ} \mathrm{C}$ (Mikhailova et al., 2009a; 2009b). The optimum $\mathrm{pH}$ of the proteinase was $\mathrm{pH} 9.5$; the proteinase is stable in a $\mathrm{pH}$ range of 7-10. More than $90 \%$ of phytase activity was retained in the presence of gastric juice of chickens ( $\mathrm{pH}$ 3.0), whereas pancreatic and intestinal juice inhibited its activity by $10 \%$. The bacillary proteinase retained up to $60 \%$ activity in the presence of gastric juice of chickens $(\mathrm{pH} 3)$. In the presence of pancreatic and intestinal juice, the proteinase's activity was fully preserved. At bile concentrations from 0.01 to $0.05 \%$ for $1 \mathrm{~h}$, the proteinase's activity remained at the control level. With an increase in concentration to $1 \%$, a $10 \%$ decrease in enzyme activity was observed. At a bile concentration of $5 \%$, the residual activity of the enzyme was $60 \%$. Its activity was not suppressed by natural inhibitors, such as trypsin inhibitor, which allows it to function in the gastrointestinal tract of chickens (Koryagina et al., 2018). Grounding on the abovementioned properties, the obtained enzymes were concluded to be prospective feed supplements for poultry.

The present work aimed to study the effect of feed additives based on bacterial phytase and proteinase on the productivity, digestibility and assimilation of nutrients of young laying hens until 18 weeks of age.

\section{Materials and Methods}

\section{Ethics Statement}

The experimental protocol was designed according to the guidelines of the current European Directive (2010/63/EU) on the care and protection of animals used for scientific purposes and approved by the Ethical Committee of the Kazan Federal University (Russian Federation, Kazan, accession number No 459/06/04/2020).

\section{Extraction and Purification of Bacterial Enzymes}

The phytase preparation was obtained on the basis of the recombinant strains of the yeast Pichia pastoris pPINK-agpP that we developed (Troshagina et al., 2018). To obtain desired amounts of phytase, the $P$. pastoris pPINK-agpP strain was cultured in a Biotron LiFlus SP30L bioreactor (Biotron, Inc., Korea). 
Following the fermentation process, yeast cells were precipitated by centrifugation and the culture fluid was collected. The residual phytase-containing supernatant was passed through a UV-0.5-30-PS hollow fiber module (Faserkraft, Russia) to concentrate the enzyme. As a result of fermentation and concentration processes, about 500 thousand units of recombinant phytase were obtained, which were then stored at $-20^{\circ} \mathrm{C}$.

Phytase activity was determined by the amount of phosphorus released during hydrolysis of the substrate sodium phytate (Sigma Aldrich, USA) according to Greiner's method (Greiner, 2004). A unit of phytase activity was taken as the amount of enzyme necessary for the cleavage of sodium phytate to form $1 \mu \mathrm{M}$ inorganic phosphate in $1 \mathrm{~min}$.

Subtilisin-like proteinase was isolated from the $B$. pumilus $7 \mathrm{p}$ strain and purified as previously described by (Koryagina et al., 2018). B. pumilus $7 \mathrm{p}$ is a natural soil isolate, which shows an increased level of subtilisinlike proteinase secretion. The bacterium was cultured in a medium with composition (g/l): Bacteriological peptone (Sigma, USA) - 20, $\mathrm{CaCl}_{2} * 2 \mathrm{H}_{2} \mathrm{O}-0.6, \mathrm{MgSO}_{4}$ * 7 $\mathrm{H}_{2} \mathrm{O}-0.5, \quad \mathrm{NaCl}-3, \quad \mathrm{MnSO}_{4}-0.1, \quad \mathrm{Na}_{2} \mathrm{HPO}_{4}-0.2$, $\mathrm{NH}_{4} \mathrm{Cl}-0.2$. A preliminary study on the dynamics of proteolytic activity showed that maximum activity occurs at the 24th $\mathrm{h}$ of growth. The supernatant was obtained by centrifugation (Beckman Avanti JXN-26 centrifuge, Beckman Coulter, Inc.) of the culture fluid for $15 \mathrm{~min}$ at $15,000 \mathrm{rpm}$. For maximum protein sorption, the supernatant was diluted (1:10) with water prior to the addition of Carboxymethylcellulose (CMC), the $\mathrm{pH}$ of the solution was adjusted to 6.3 . CMC, (Sigma, USA) was equilibrated with $0.02 \mathrm{M}$ Na-acetate buffer ( $\mathrm{pH}$ 6.3), added to the enzyme solution and gently stirred for $90 \mathrm{~min}$ at room temperature. After the natural deposition of the sorbent, the supernatant was discarded. Proteolytic activity in the supernatant did not exceed $0.005 \mathrm{u} / \mathrm{mL}$. The sorbent was placed on a glass column $(\varnothing 3 \mathrm{~cm}$, height $20 \mathrm{~cm}$ ) and washed with $0.02 \mathrm{M}$ sodium acetate buffer, (pH 6.3). Elution was performed with $0.2 \mathrm{M}$ sodium acetate, ( $\mathrm{pH}$ 6.3). Fractions with high proteolytic activity were collected and pooled. With the aid of CM chromatography, a proteinase preparation was obtained with a purification degree of 20 and with a yield of $29.3 \%$ the specific activity of proteinase was determined to be $0.1 \mathrm{u} / \mathrm{mg}$ protein (Table 1). Proteinase activity was determined by the hydrolysis of azocasein (Sigma, USA) according to the method described in (Sabirova et al., 2010).

The unit of activity was taken as the amount of the enzyme hydrolyzing $1 \mu \mathrm{g}$ of the substrate in 1 min under the experimental conditions.

SDS-PAGE electrophoresis (Laemmli, 1970) of the protein fraction following the CMC purification phase showed the presence of a protein with a molecular weight of $28 \mathrm{kDa}$, which corresponds to the molecular weight of $B$. pumilus subtilisin-like proteinase (Appendix, Fig. S1).

\section{Management of Layer Birds}

A total of 360 1-day-old Hisex Brown hens were weighed individually and randomly assigned to 3 treatments with 4 replicates of 30 birds each. The treatments consisted of 3 distinct diets: (1) Control group: Basic diet without proteinase and phytase, (2) experimental group A (Proteinase group): Basic diet with the addition of proteinase at a concentration of $10 \mathrm{U} / \mathrm{kg}$, (3) experimental group B (Phytase group): Basic diet with the addition of phytase at a concentration of 1000 FTU/kg. Feed pellets were sprayed with aqueous solutions of enzymes at the desired concentrations at room temperature. During the first 5 days of age, chickens of all groups exclusively received the basic diet. From the 6th day of age, birds of the experimental groups were fed with their respective experimental diets. The ingredient and nutrient contents of basic diet are shown in Table 2. Each 30-birds group in each repeat of the experiment was placed in a separate cages $(1630 \times 980 \times 680 \mathrm{~mm})$ under controlled climate conditions with temperature maintained at $18^{\circ} \mathrm{C}, 65 \%$ relative humidity, alternating lighting period (16L:8D) and light intensity of 12 lux. Feed and water were available ad libitum. The experiment lasted for a total of 112 days.

\section{Hematological and Biochemical Analysis of Chicken Blood}

For hematological and biochemical analysis of venous blood collection was carried out in 5 birds, randomly sampled from each group on days 30, 60 and 90 of age. Whole blood heparinized and stabilized in Trilon B was used. With the aid of MicroCC-20 Plus (USA) and BioChem SA (USA) analyzers, blood parameters such as erythrocytes, leukocytes, hemoglobin, hematocrit, total protein, urea, creatinine, calcium, inorganic phosphorus, as well as aspartate, alanine and aminotransferase activities were measured.

Table 1: Chromatography of the B. pumilus $7 \mathrm{p}$ subtilisin-like proteinase

\begin{tabular}{|c|c|c|c|c|c|c|c|}
\hline Purification phase & $\mathrm{V}, \mathrm{mL}$ & Protein, $\mathrm{A}_{280}$ & $\begin{array}{l}\text { Activity, } \\
\mathrm{U} / \mathrm{mL}\end{array}$ & $\begin{array}{l}\text { Total } \\
\text { activity, } \mathrm{U}\end{array}$ & $\begin{array}{l}\text { Specific } \\
\text { activity, U/mg }\end{array}$ & $\begin{array}{l}\text { Purification } \\
\text { degree }\end{array}$ & Yield, \% \\
\hline Culture fluid & 12200 & 410 & 2.09 & 25498 & 0.005 & 1 & 100 \\
\hline CM-cellulose & 570 & 131 & 13.10 & 7467 & 0.100 & 20 & 29.3 \\
\hline
\end{tabular}


Table 2: Diet composition of laying hens

\begin{tabular}{|c|c|c|c|}
\hline \multirow[b]{2}{*}{ Ingredients } & \multicolumn{3}{|c|}{ Age, weeks } \\
\hline & $1-8$ & $8-16$ & 16-18 \\
\hline Corn, $\%$ & 48.4 & 36 & 10.4 \\
\hline Wheat, \% & 20.3 & 30.2 & 48 \\
\hline Barley, \% & - & - & 30 \\
\hline Soybean meal, \% & 12.8 & 2 & - \\
\hline Fish powder, $\%$ & 1 & - & - \\
\hline Sunflower meal, \% & 12.8 & 19.5 & 2 \\
\hline Common salt, $\%$ & 0.3 & 0.3 & 0.4 \\
\hline Chalk, \% & 3.0 & 2.4 & 1.2 \\
\hline Methionine, $\%$ & 0.1 & - & - \\
\hline Lysine, \% & 0.1 & 0.2 & - \\
\hline Monocalcium phosphate, $\%$ & 1.2 & 1 & - \\
\hline Extruded soy, \% & - & 8.4 & - \\
\hline Herbal flour, $\%$ & - & - & 6 \\
\hline Meat and bone meal, $\%$ & - & - & 2 \\
\hline
\end{tabular}

\section{Assessment of Productivity, Digestibility and} Nutrient Absorption in Birds

Poultry growth was assessed, by monitoring live weight indicators at the beginning and end of each age period. The absolute (BW) and average daily weight gain were calculated. The safety of food additives for birds was determined by monitoring the safety in each group of birds, taking into account the cause of death. To study the effect of the addition of proteinase and phytase on the digestibility and assimilation of nutrients by birds, a balance test, involving two periods (a preliminary duration of 6 days and an accounting duration of 5 days) was carried out. The birds were kept in cages with a meshed floor, under which frames made of plastic film were installed to collect droppings. In each group of birds, the quantity and chemical composition of the consumed feed and the collected litter were taken into account. Chemical analysis of feed and litter was carried out using the methods described in GOST 31640-2012, 32933-2014 and 31675-2012 (GOST 31640-2012 "Feed. Methods for determining the dry matter content" GOST 32933-2014 "Feed. Compound feed. Method for determining crude ash", GOST 31675-2012 "Feed. Methods for determining crude fiber content with intermediate filtration", Kjeldahl nitrogen determination method, Soxhlet extraction method for determining fat). The digestibility coefficient was calculated as the ratio of digestible to absorbed nutrients, expressed as a percentage. Feed Conversion Ratio (FCR) was obtained on the 8th and 16th weeks of age and the European Productivity Index (EPI) of layers was calculated using the formula:

$$
E P I=\frac{\text { Viabiilty }(\%) \times B W(\mathrm{~kg}) \times 100}{A g e(d) \times F C R(\mathrm{~kg} \text { feed intake } / \mathrm{kg} \text { gain })}
$$

\section{The Effect of Enzymes on the Structure of Internal Organs}

To study the effect of enzymes on the structure of internal organs after 112 days of growth, 3 randomly sampled birds each from the control and experimental groups were slaughtered. After the slaughter of laying hens, the spleen, liver and heart were collected and tissue samples $(5 \times 5 \times 1.5 \mathrm{~cm}$ in size $)$ of the internal organs were taken for the histological analysis. The material was fixed in a $10 \%$ aqueous solution of neutral formalin for three days. Fixed pieces of organs were dried, treated with chloroform, placed in blocks of paraffin wax, cut off with a thickness of $5 \mu \mathrm{m}$, mounted on slides and stained with hematoxylin and eosin. Histological sections were examined in transmitted light using a Leica DM 1000 microscope under oil immersion. Photographs were taken with a Nikon coolpix 4500 digital camera.

\section{Statistical Analysis}

Statistical processing of the results was performed in Graph Pad Prism, Graph Pad Software, version 8.0 (LA Jolla, CA, USA) using a two-way ANALYSIS Of Variance (ANOVA) and Tukey test for multiple pairwise comparison of quantitative indicators of the different groups. The results were presented as the mean $\pm \mathrm{SD}$, considering $P$ value $<0.05$ as significant.

\section{Results and Discussion}

To study the effect of phytase and proteinase on the digestibility and assimilation of nutrients (calcium, phosphorus and nitrogen) in layer feed, balance tests were performed on young laying hens at 8 and 16 weeks of age. The daily ingested and excreted amounts of elements were compared and the digestibility of the nutrients was calculated based on the nutritional value of the feed (Table 3 ). 
The chemical composition of the complex feed corresponded to the nutritional value for this type of poultry in accordance with GOST 18221-99 "Complete feed for full-time poultry. Technical conditions". The digestibility of nutrients entering the body depends on the enzymatic activity of secretory glands of the gastrointestinal tract. The introduction of exogenous phytases and proteinases with retained catalytic function, under optimal conditions, in the gastrointestinal tract is aimed at increasing the digestibility of nutrients in the feed mixture and reducing the cost of feed for growing young birds. From our data, the final feed mixture contained cereal components with phosphates at an amount of $6 \mathrm{mg} / \mathrm{g}$ of feed.

In birds aged 1 to 8 weeks old in the experimental group that received bacterial proteinase (Proteinase group) the protein digestibility coefficient was $89.1 \pm 2.34 \%$. This was $7.9 \%$ more in comparison to the control group (Control group) and 6\% more in comparison to the phytase receiving experimental group (Phytase group) $[\mathrm{F}(2.6)=8.264, \mathrm{p}=0.018]$ (Table 4). This trend was continually observed in young laying hens likewise from the 8th to 16 th weeks of age: The protein digestibility coefficient remained the highest in the Proteinase group and amounted to $67.3 \pm 2.06 \%$ as against $61.1 \pm 1.60 \%$ and $64.2 \pm 2.14 \%$ in the Control and Phytase groups, respectively [F (2.6) = $10.688, p=0.02$ ] (Table 4). No significant statistical difference $(p>0.05)$ was detected in the digestibility of dry matter and fat among the three groups between the 1 st and 16th weeks of age. From the obtained data, we can infer that phytase and proteinase do not take a significant part in fat metabolism due to their specificity in function. Interestingly, the influence of phytase and proteinase on the absorption of fiber by birds decreases with age. We suppose that this is due to the changes in the structure of the gut microbiota of the birds, which depends more on the age of the bird than on the diet (Ballou et al., 2016). The phyla Bacteroides and Firmicutes, which are dominant in the intestines of adult birds play an important role in the metabolism and degradation of complex polysaccharides (Magnúsdóttir et al., 2017; Medvecky et al., 2018). Thus, their influence on the absorption of fibers is expected. Under the conditions of a well-formed microbiome (8-16 weeks), exogenous phytase and proteinase may show a minimal effect on the absorption of fiber. However, in young birds (1-8 weeks), they can contribute to more effective fiber absorption.

The digestibility coefficient of fat was higher by a $5 \%$ range in birds of the experimental groups [F (2.6) $=7.050, \mathrm{p}=0.026]$. According to our data, a steady rise in the digestibility coefficient of protein and organic compounds is observed in birds that received additional bacterial enzymes to basic feed mixture. Throughout the experiment, the addition of exogenous proteinase at a concentration of $10 \mathrm{U} / \mathrm{kg}$ to the diet contributed to an increase in the digestibility of proteins due to a more effective breakdown of the protein components of the feed mixture.

Table 3: Nutritional value of the combined feed used in the balance experiment, $\mathrm{g}$

\begin{tabular}{ll}
\hline Component & Amount per $100 \mathrm{~g}$ \\
\hline Weeks 1- 8 & \\
Crude protein & 19.5 \\
Crude fats & 5.00 \\
Crude fiber & 3.22 \\
Calcium & 1.0 \\
Phosphorus & 0.44 \\
Weeks 8 - 16 & \\
Crude protein & 18.3 \\
Crude fats & 4.1 \\
Crude fiber & 3.6 \\
Calcium & 0.9 \\
Phosphorus & 0.40 \\
\hline
\end{tabular}

Table 4: Digestibility coefficients of compound feed nutrients, $\%, \pm$ SD

\begin{tabular}{|c|c|c|c|c|}
\hline \multirow[b]{2}{*}{ Indicators } & \multicolumn{3}{|l|}{ Groups } & \multirow[b]{2}{*}{$\mathrm{p}=$} \\
\hline & Control group & Proteinase group & Phytase group & \\
\hline \multicolumn{5}{|l|}{ Weeks $1-8$} \\
\hline Protein digestibility & $81.2 \pm 2.11$ & $89.1 \pm 2.34$ & $83.4 \pm 1.95$ & 0.018 \\
\hline Dry matter & $62.7 \pm 2.25$ & $67.6 \pm 2.12$ & $63.5 \pm 2.55$ & $0.083^{*}$ \\
\hline Fiber & $15.3 \pm 0.77$ & $18.4 \pm 0.63$ & $16.9 \pm 0.70$ & 0.02 \\
\hline Fat & $85.3 \pm 2.91$ & $92.4 \pm 3.25$ & $89.4 \pm 3.18$ & $0.087^{*}$ \\
\hline \multicolumn{5}{|l|}{ Weeks 8-16 } \\
\hline Protein digestibility & $61.1 \pm 1.60$ & $67.3 \pm 2.06$ & $64.2 \pm 2.14$ & 0.02 \\
\hline Dry matter & $52.9 \pm 2.76$ & $55.8 \pm 1.84$ & $54.1 \pm 3.11$ & $0.45^{*}$ \\
\hline Fiber & $10.1 \pm 0.66$ & $11.9 \pm 0.81$ & $11.6 \pm 0.79$ & $0.055^{*}$ \\
\hline Fat & $62.7 \pm 3.14$ & $68.7 \pm 3.90$ & $67.7 \pm 3.47$ & $0.16^{*}$ \\
\hline
\end{tabular}

*Not significant value $(\mathrm{p}>0.05)$ 
A high dietary protein content remains essential for young birds, owing to the inadequate secretion of proteases by their pancreas and a subsequent reduction in the level of protein hydrolysis and the absorption of amino acids (Angel et al., 2011). Proteinases are enzymes that hydrolyze high polymer proteins to amino acids, thus added feed enzymes are most effective precisely during the early development of poultry. This paves way for an increase in digestible protein indicators by up to $\sim 4 \%$ (Kononenko, 2016).

Data analysis of the balance of calcium, phosphorus and nitrogen in the three groups of young laying hens aged 1 and 16 weeks was conducted. In birds aged 8 weeks, the digestibility coefficient of calcium in both experimental groups was higher, relative to the control and amounted to $57.1 \pm 0.2$ for the Proteinase group and $52.8 \pm 0.3$ for the Phytase group $[\mathrm{F}(2.6)=36.5, \mathrm{p}=$ $<0.0001]$ (Table 5). The digestibility coefficient of phosphorus for the selected period was highest in the Phytase group and amounted to $65.5 \pm 0.4 \%$, which exceeded the Control group by $22.2 \%$ and the Proteinase group by $13.8 \%[\mathrm{~F}(2.6)=170.59, \mathrm{p}=$ 0.000005] (Table 5). The digestibility coefficient of nitrogen in the experimental group with proteinase exceeded the indicators of the control group by $7.5 \%$ and that of the Phytase group by $5.6 \%[\mathrm{~F}(2,6)=103$, p $=0.00002]($ Table 5$)$.

Table 5: Calcium, phosphorus and nitrogen balance in birds from weeks 1 to $8, \pm$ SD

\begin{tabular}{|c|c|c|c|c|}
\hline \multirow[b]{2}{*}{ Feed parameters } & \multicolumn{3}{|l|}{ Groups } & \multirow[b]{2}{*}{$\mathrm{p}=$} \\
\hline & Control group & Proteinase group & Phytase group & \\
\hline \multicolumn{5}{|l|}{ Calcium } \\
\hline Amount ingested, $\mathrm{g}$ & $0.55 \pm 0.03$ & $0.56 \pm 0.03$ & $0.53 \pm 0.03$ & $0.5^{*}$ \\
\hline Amount excreted, $\mathrm{g}$ & $0.33 \pm 0.02$ & $0.24 \pm 0.02$ & $0.25 \pm 0.02$ & 0.002 \\
\hline Amount digested, $\mathrm{g}$ & $0.22 \pm 0.01$ & $0.32 \pm 0.01$ & $0.28 \pm 0.01$ & $<0.0001$ \\
\hline Digestibility coefficient, $\%$ & $40.0 \pm 0.1$ & $57.1 \pm 0.2$ & $52.8 \pm 0.3$ & $<0.0001$ \\
\hline \multicolumn{5}{|l|}{ Phosphorus } \\
\hline Amount ingested, $\mathrm{g}$ & $0.30 \pm 0.02$ & $0.29 \pm 0.01$ & $0.29 \pm 0.01$ & $0.63^{*}$ \\
\hline Amount excreted, $\mathrm{g}$ & $0.17 \pm 0.007$ & $0.14 \pm 0.009$ & $0.10 \pm 0.007$ & $<0.0001$ \\
\hline Amount digested, $\mathrm{g}$ & $0.13 \pm 0.08$ & $0.15 \pm 0.06$ & $0.19 \pm 0.05$ & $0.545^{*}$ \\
\hline Digestibility coefficient, $\%$ & $43.3 \pm 0.5$ & $51.7 \pm 0.5$ & $65.5 \pm 0.4$ & $<0.0001$ \\
\hline \multicolumn{5}{|l|}{ Nitrogen } \\
\hline Amount ingested, $\mathrm{g}$ & $1.36 \pm 0.04$ & $1.38 \pm 0.03$ & $1.37 \pm 0.04$ & $0.809^{*}$ \\
\hline Amount excreted, $\mathrm{g}$ & $0.90 \pm 0.02$ & $0.81 \pm 0.02$ & $0.83 \pm 0.03$ & 0.008 \\
\hline Amount digested, $\mathrm{g}$ & $0.46 \pm 0.01$ & $0.57 \pm 0.01$ & $0.54 \pm 0.02$ & 0.0002 \\
\hline Digestibility coefficient, $\%$ & $33.8 \pm 0.01$ & $41.3 \pm 0.01$ & $39.4 \pm 0.01$ & $<0.0001$ \\
\hline
\end{tabular}

*Not significant value $(\mathrm{p}>0.05)$

Table 6: Phosphorus and nitrogen balance in birds from weeks 8 to $16, \pm$ SD

\begin{tabular}{|c|c|c|c|c|}
\hline \multirow[b]{2}{*}{ Feed parameters } & \multicolumn{3}{|l|}{ Groups } & \multirow[b]{2}{*}{$\mathrm{p}=$} \\
\hline & Control group & Proteinase group & Phytase group & \\
\hline \multicolumn{5}{|l|}{ Calcium } \\
\hline Amount ingested, $\mathrm{g}$ & $0.60 \pm 0.02$ & $0.61 \pm 0.03$ & $0.60 \pm 0.04$ & $0.903 *$ \\
\hline Amount excreted, $\mathrm{g}$ & $0.36 \pm 0.03$ & $0.32 \pm 0.02$ & $0.33 \pm 0.02$ & $0.182 *$ \\
\hline Amount digested, $\mathrm{g}$ & $0.24 \pm 0.02$ & $0.29 \pm 0.01$ & $0.27 \pm 0.01$ & 0.02 \\
\hline Digestibility coefficient, $\%$ & $40.0 \pm 0.01$ & $47.5 \pm 0.01$ & $45.0 \pm 0.01$ & $<0.0001$ \\
\hline \multicolumn{5}{|l|}{ Phosphorus } \\
\hline Amount ingested, $\mathrm{g}$ & $0.25 \pm 0.01$ & $0.24 \pm 0.02$ & $0.25 \pm 0.01$ & $0.63 *$ \\
\hline Amount excreted, $g$ & $0.16 \pm 0.006$ & $0.13 \pm 0.008$ & $0.09 \pm 0.004$ & 0.435 \\
\hline Amount digested, $\mathrm{g}$ & $0.09 \pm 0.03$ & $0.11 \pm 0.05$ & $0.16 \pm 0.05$ & $0.218^{*}$ \\
\hline Digestibility coefficient, $\%$ & $36.0 \pm 0.3$ & $45.8 \pm 0.4$ & $64.0 \pm 0.3$ & $<0.0001$ \\
\hline \multicolumn{5}{|l|}{ Nitrogen } \\
\hline Amount ingested, $\mathrm{g}$ & $1.68 \pm 0.02$ & $1.69 \pm 0.01$ & $1.69 \pm 0.03$ & $0.813^{*}$ \\
\hline Amount excreted, $\mathrm{g}$ & $0.52 \pm 0.04$ & $0.43 \pm 0.02$ & $0.48 \pm 0.02$ & 0.022 \\
\hline Amount digested, $\mathrm{g}$ & $1.16 \pm 0.01$ & $1.26 \pm 0.02$ & $1.21 \pm 0.03$ & 0.0039 \\
\hline Digestibility coefficient, $\%$ & $69.0 \pm 0.01$ & $74.5 \pm 0.01$ & $71.6 \pm 0.02$ & $<0.0001$ \\
\hline
\end{tabular}

*Not significant value $(\mathrm{p}>0.05)$ 
In young laying hens aged 8 to 16 weeks, the calcium digestibility coefficient in the Proteinase and Phytase groups surpassed the Control group by 7.5 and $5 \%$, respectively $[\mathrm{F}(2.6)=12, p<0.0001]$ (Table 6$)$. In the case of phosphorus, its digestibility remained the highest in the Phytase group and amounted to $64.0 \pm 0.3 \%$, as against $36 \pm 0.3$ and $45.8 \pm 0.4 \%$ for the Control and Proteinase groups, respectively $[\mathrm{F}(2.6)=198.3, \mathrm{p}=$ 0.000003]. At this stage of growth, the digestibility coefficient of nitrogen in the Proteinase group was $74.5 \pm 0.01 \%$, which was 5.5 and $2.9 \%$ higher than the Control and Phytase groups, accordingly $[\mathrm{F}(2.6)=$ 17.85, $p<0.0001$ ] (Table 6).

One of the most important elements of the mineral nutrition for laying hens is calcium. In addition to its vital functions as the main component of bone structure, participation in the acid-base balance and many enzymatic systems, calcium is also the main component of the eggshell. It is estimated that each egg contains $2.2 \mathrm{~g}$ of calcium, which is mainly present in the eggshell (Pelicia et al., 2009). The positive values resulting from the calcium balance indicates that using each of the studied enzymes, increases the coefficient of calcium digestibility, especially to a greater extent during the 1 st to 8 th weeks of age (Table 5 and 6).

Phytic acid, being a primary grain feed component (50 to 80\%) (Selle and Ravindran, 2007), exhibits chelating properties by binding metal ions and thus, reducing the bioavailability of calcium, magnesium and other minerals. The release or breakdown of phytic acid occurs during phytase-mediated hydrolysis (Rao et al., 2009; Yao et al., 2012). With regard to the more elevated digestibility coefficient of calcium in the presence of proteinase, we suggest a possible stimulating effect of enzyme on the system of cells responsible for calcium metabolism. On the whole, both enzymes portray a beneficial effect on the digestibility of calcium in laying hens, which is vital for this category of bird.

For the entire period of growth, data on phosphorus digestibility coefficient showed that supplementing layer diet with bacterial phytase at a concentration of 1000 $\mathrm{U} / \mathrm{kg}$ of feed facilitated the utilization of feed compounds with inaccessible phosphorus (phytate) and led to a reduction in the amount of undigested phosphate in the litter. Without the addition of phytase to the diet (control group), the digestibility coefficient of phosphorus was almost halved; a substantial amount of the phosphorus was excreted with litter under these conditions $(p<0.05)$ (Table 5 and 6).

Analysis of the nitrogen balance showed that, the digestibility coefficient of nitrogen for the Proteinase group was higher in all cases in comparison to corresponding values recorded for the Control and Phytase group $(p<0.05)$. The digestibility of feed protein in the presence of enzyme additives and in particular proteinase, exerted a positive effect on the nitrogen balance in the bird (Tables 5 and 6). With equal amounts of nitrogen available to birds in all experimental variants, its loss through the litter decreased with the use of enzyme supplement. This was due to an elevated bioavailability of amino acids as a result of effective hydrolysis of plant proteins. In addition, bacterial proteinases are stable, nonspecific, exhibit high molecular activity and can reduce the negative effects of animal proteinase inhibitors, allergens and other digestive blockers (Cowieson et al., 2005).

When developing and evaluating the effect of new feed additives on the physiological functioning of a bird, systematic blood tests are important for diagnosing metabolic disorders. The hematological (the number of red blood cells, leukocytes, hemaglobin and hematocrit) and biochemical (total protein, urea, creatinine, total calcium, inorganic phosphorus, aspartate aminotransferase and alanine aminotransferase) parameters were analyzed on days 30, 60 and 90. The results showed that blood parameters varied within the normal range in control and experimental birds. The ratio of calcium to phosphorus $(\mathrm{Ca} / \mathrm{P})$ in the blood serum remained above 1 , in accordance with the physiological norm of laying hens in all variants (Appendix, Tables S1, S2). Based on the obtained data, we concluded that the digestive enzymes used by us at the studied concentration do not exert a negative influence on the metabolism and gastrointestinal tract functioning in the birds.

Feed additives in the diet of laying hens had an impact on the dynamics of live weight of poultry. Taking into account the starting live weight and at the final for each age period, the absolute and average daily growth indices were estimated. Notwithstanding the comparable starting live weights in all variants $(\sim 51.6-$ $52.9 \mathrm{~g}$ ), live weights of $506.1 \pm 6.18 \mathrm{~g}, 520.9 \pm 5.6 \mathrm{~g}$ and $519.3 \pm 5.11 \mathrm{~g}$ were recorded for the Control, Proteinase and Phytase groups on the 8th week, respectively (Table 7). Thus, a higher increase in live weight of young layers in the experimental groups was achieved $[\mathrm{F}(2.6)=8.385, \mathrm{p}=0.04]$. The difference in absolute live weight gain of the experimental birds relative to that of the Control group is as a result of a higher average daily gain $(p<0.05)$ (Table 7$)$.

In birds aged 16 weeks, the live weights were $1015.7 \pm 7.41 \mathrm{~g}, 1036.5 \pm 5.1 \mathrm{~g}$ and $1030.8 \pm 4.5 \mathrm{~g}$ for the Control, Proteinase and Phytase groups, respectively [F $(2.6)=11.166, \mathrm{p}=0.012]$. The absolute weight gain in the Control group was $509.6 \pm 0.02 \mathrm{~g}$, while $520.6 \pm 0.02 \mathrm{~g}$ and $518.5 \pm 0.04 \mathrm{~g}$ were recorded for the in the Proteinase and Phytase groups [F $(2.6)=35.393, p<0.001]$. The average daily weight gain was higher in the Proteinase group $(11.56 \pm 0.02 \mathrm{~g})$ as compared to the Control $(9.11 \pm 0.02 \mathrm{~g})$ and Phytase groups $(11.52 \pm 0.04 \mathrm{~g})$, respectively $[\mathrm{F}(2.6)=8.375, p<0.001]$. 
Table 7: Live weight of young chickens at different ages, \pm SD

\begin{tabular}{lllll} 
& Groups & & & \\
& - & & & \\
Measured parameter & Control group & Proteinase group & Phytase group & \\
\hline Weeks 1 to 8 & & & & \\
Starting live weight, g & $52.9 \pm 1.15$ & $51.6 \pm 1.23$ & $51.8 \pm 1.55$ & $0.48^{*}$ \\
Live weight at the end of the period, g. & $506.1 \pm 6.18$ & $520.9 \pm 5.6$ & $519.3 \pm 5.11$ & 0.04 \\
Absolute weight gain, g. & $453.2 \pm \pm 5.1$ & $469.3 \pm 4.5$ & $467.5 \pm 4.1$ & 0.0096 \\
Average daily weight gain, g. & $9.23 \pm 0.12$ & $9.57 \pm 0.1$ & $9.54 \pm 0.11$ & 0.02 \\
Amount of feed spent per bird, kg & $1.843 \pm 0.01$ & $1.750 \pm 0.01$ & $1.760 \pm 0.01$ & $<0.001$ \\
Feed Conversion Ratio (FCR) & $4.06 \pm 0.05$ & $3.73 \pm 0.045$ & $3.76 \pm 0.04$ & $<0002$ \\
European Productivity Index (EPI) & $22.77 \pm 0.06$ & $25.66 \pm 0.08$ & $25.34 \pm 0.04$ & $<0.001$ \\
Weeks 8 to 16 & & & & \\
Starting live weight, g & $506.1 \pm 6.18$ & $515.9 \pm 5.6$ & $512.3 \pm 5.11$ & $0.18^{*}$ \\
Live weight at the end of the period, g. & $1015.7 \pm 7.41$ & $1036.5 \pm 5.1$ & $1030.8 \pm 4.5$ & $<012$ \\
Absolute weight gain, g. & $509.6 \pm 0.02$ & $520.6 \pm 0.02$ & $518.5 \pm 0.04$ & $<0.001$ \\
Average daily weight gain, g. & $9.11 \pm 0.02$ & $11.56 \pm 0.02$ & $11.52 \pm 0.04$ & $<0.001$ \\
Amount of feed spent per bird, kg & $3.797 \pm 0.01$ & $3.572 \pm 0.01$ & $3.581 \pm 0.01$ & $<0.001$ \\
Feed Conversion Ratio (FCR) & $7.45 \pm 0.02$ & $6.86 \pm 0.02$ & $6.9 \pm 0.02$ & $<0.001$ \\
European Productivity Index (EPI) & $12.2 \pm 0.03$ & $13.49 \pm 0.04$ & $13.32 \pm 0.01$ & $<0.001$ \\
\hline *Not significant value (p>0.05) & & & &
\end{tabular}

*Not significant value $(\mathrm{p}>0.05)$

Bird safety for the entire experimental period was $100 \%$. The obtained differences in the live weight of young laying hens was probably due to the digestibility of nutrients in the diet (Table 4). At 8 weeks of age, the digestibility of dry matter was $62.7 \pm 2.25 \%$ for the control group, whereas in proteinase and phytase fed birds it increased to $67.6 \pm 2.12 \%$ and $63.5 \pm 2.55(p<0.05)$, respectively. A similar pattern was observed in the digestibility of organic matter (Table 4).

Histological studies of parenchymal organs (liver, spleen and myocardium) in the control and experimental groups of young laying hens did not reveal any abnormalities (Appendix, Fig. S2-S4,).

The most important indicator during a comprehensive assessment of the effectiveness of animal feed is the cost of feed. This is due to the fact that, in bird management, feed accounts for more than $70 \%$ of production costs. To manage birds for the first 8 weeks, we spent $1.843 \pm 0.01$ $\mathrm{kg}$ of feed per head for the control group, while $1.750 \pm 0.01 \mathrm{~kg}$ and $1.760 \pm 0.01 \mathrm{~kg}$ were spent per head in the Proteinase and Phytase groups, respectively. For the subsequent 8 to 16 weeks, the minimal feed cost was registered in Proteinase group $(3.572 \pm 0.01 \mathrm{~kg}$ per bird), which was $5.9 \%$ less in comparison to the control group. With regard to the Phytase group, the cost of feed per head amounted to $3.581 \pm 0.01 \mathrm{~kg}$, which surpassed the Control group by $5.6 \%$ [F $(2.6)=580.40, p<0.001]$.

At the final stage of the study, we assessed feed conversion and the European productivity index, which is used to evaluate the economic feasibility of using the studied feed additive.

The results demonstrated that the addition of proteinase $(10 \mathrm{U} / \mathrm{kg})$ and phytase $(1000 \mathrm{FTU} / \mathrm{kg})$ to diet of laying hen enhances the total and daily weight gain, while decreasing the FCR. The absolute weight gain of the in the Proteinase group birds was higher than that of the control group by $3.4 \%(p<0.001)$ for the first 8 weeks and $1.1 \%(p<0.001)$ at the end of the experiment. The Feed Conversion Ratio (FCR) for the entire 16 week period was lower in the experimental groups $(6.86 \pm 0.02$ for Proteinase group; and $6.9 \pm 0.02$ for the Phytase group) in contrast to the Control group $(7.45 \pm 0.02)$ [F $(2.6)=612.25, p=0.001]$.

\section{Conclusion}

Commercial phytases and proteinases from diverse sources are checked and confirmed for their prospective use as probiotics for all types of farm birds and animals. We have demonstrated that the new enzymes, subtilisinlike serine protease of $B$. pumilus $7 \mathrm{p}$ and histidine acid 3-phytase of Pantoea sp. 3.5.1, also show good results. Adding phytase at a concentration of $1000 \mathrm{FTU} / \mathrm{kg}$ of feed contributes to better absorption of calcium and phosphorus. The inclusion of proteinase in the feed at a concentration of $10 \mathrm{U} / \mathrm{kg}$ increases the digestibility of calcium, nitrogen and crude protein. As a result, both enzymes reduce feed cost per experimental fowl by more than $5 \%$. On the whole, the daily weight gain of the birds increased by an average of $3 \%$ during the study. The enzymes used in the study were secreted by natural bacterial strains isolated from the soils of the Tatarstan region, where their intended use is expected. B. pumilus 7 p subtilisin-like proteinase has a naturally high proteolytic activity, as well as increased stability under changing $\mathrm{pH}$ conditions. This allows the enzyme to not only "survive" in the aggressively acidic environment of the poultry stomach, but also completely restore its catalytic activity when it enters the more alkaline environment of the poultry intestine. The bacterial phytase from Pantoea sp. 3.5.1 is glycosylated during 
expression in cells of the methylotrophic yeast Pichia pastoris and becomes more resistant to elevated temperature and acidic $\mathrm{pH}$ values: The $\mathrm{pH}$-optimum of the enzyme changes from $\mathrm{pH} 4.5$ to $\mathrm{pH} 3.0$, which causes a more effective hydrolysis of its substrate in the acidic environment of the poultry stomach. Both enzymes were isolated and studied in detail in our laboratory. They have convincingly shown their effectiveness as feed additives for laying hens, providing an increase in the main important indicators of poultry productivity.

\section{Acknowledgement}

This work was performed in accordance with the Russian Government Program of Competitive Growth of Kazan Federal University. Russian Science Foundation funded the reported study, according to the research project No 16-16-04062.

\section{Author Contributions}

The authors of the manuscript have made a significant contribution to the work and fully agree with the content of the manuscript.

Smolentsev Sergei Yur'evich: Development of experimental design, control of work with poultry in the vivarium, analysis of the results obtained and histological studies.

Rudakova Natalia Leonidovna: Preparation of proteinase (isolation and purification) and writing of the manuscript (proofreading, author for correspondence).

Koryagina Anastasia Olegovna: Preparation of proteinase (isolation and purification).

Bulmakova Daria Sergeevna: Preparation of phytase (isolation and purification).

Suleymanova Aliya Damirovna: Preparation of phytase (isolation and purification).

Mardanova Ayslu Mirkasimovna: Supervision of experimental work, analysis of the results obtained, participation in writing the article (working with sources).

Sharipova Margarita Rashidovna: Project head, development of the experiment plan, Manuscript design and writing.

\section{Conflict of Interest}

The authors declare no conflicts of interest.

\section{References}

Abd El-Hack, M. E., Alagawany, M., Arif, M., Emam, M., Saeed, M., Arain, M. A., ... \& Khan, R. U. (2018). The uses of microbial phytase as a feed additive in poultry nutrition-a review. Annals of Animal Science, 18(3), 639-658.
Angel, C. R., Saylor, W., Vieira, S. L., \& Ward, N. (2011). Effects of a monocomponent protease on performance and protein utilization in 7-to 22day-old broiler chickens. Poultry science, 90(10), 2281-2286.

Ballou, A. L., Ali, R. A., Mendoza, M. A., Ellis, J. C., Hassan, H. M., Croom, W. J., \& Koci, M. D. (2016). Development of the chick microbiome: how early exposure influences future microbial diversity. Frontiers in veterinary science, $3,2$.

Borda-Molina, D., Zuber, T., Siegert, W., CamarinhaSilva, A., Feuerstein, D., \& Rodehutscord, M. (2019). Effects of protease and phytase supplements on small intestinal microbiota and amino acid digestibility in broiler chickens. Poultry science, 98(7), 2906-2918.

Cowieson, A. J., Hruby, M., \& Faurschou Isaksen, M. (2005). The effect of conditioning temperature and exogenous xylanase addition on the viscosity of wheat-based diets and the performance of broiler chickens. British Poultry Science, 46(6), 717-724.

Dersjant-Li, Y., Awati, A., Schulze, H., \& Partridge, G. (2015). Phytase in non-ruminant animal nutrition: a critical review on phytase activities in the gastrointestinal tract and influencing factors. Journal of the Science of Food and Agriculture, 95(5), 878-896.

Dozier III, W. A., Corzo, A., Kidd, M. T., Tillman, P. B., McMurtry, J. P., \& Branton, S. L. (2010). Digestible lysine requirements of male broilers from 28 to 42 days of age. Poultry Science, 89(10), 2173-2182.

Giannenas, I., Bonos, E., Anestis, V., Filioussis, G., Papanastasiou, D. K., Bartzanas, T., ... \& Skoufos, I. (2017). Effects of protease addition and replacement of soybean meal by corn gluten meal on the growth of broilers and on the environmental performances of a broiler production system in greece. PloS one, 12(1), e0169511.

Greiner, R. (2004). Degradation of myo-inositol hexakisphosphate by a phytate-degrading enzyme from Pantoea agglomerans. The Protein Journal, 23(8), 577-585.

Hassanien, H. H. M., \& Sanaa, H. M. E. (2011). Comparison difference levels of phytase enzyme supplementation on laying hen performance, egg quality and some blood parameters. Asian Journal of Poultry Science, 5(2), 77-85.

Jiang, J., Wu, H., Zhu, D., Yang, J., Huang, J., Gao, S., \& Lv, G. (2020). Dietary Supplementation with Phytase and Protease Improves Growth Performance, Serum Metabolism Status and Intestinal Digestive Enzyme Activities in Meat Ducks. Animals, 10(2), 268. 
Kim, J. H., Pitargue, F. M., Jung, H., Han, G. P., Choi, H. S., \& Kil, D. Y. (2017). Effect of superdosing phytase on productive performance and egg quality in laying hens. Asian-Australasian journal of animal sciences, 30(7), 994.

Kononenko, S. I. (2016). Ways of reduction of adverse feeding effect on animals. Polythematic network electronic scientific journal of the Kuban State Agrarian University. 119(05). http://ej.kubagro.ru/2016/05/pdf/21.pdf

Koryagina, A. O., Rudakova, N. L., Lutfullin, M. T., Khadieva, G. F., Tojmentseva, A. A., Mardanova, A. M., \& Sharipova, M. R. (2018). Gene constructbased serine protease of Bacillus pumilus as a feed additive for poultry farming. Agricultural Biology.

Laemmli, U. K. (1970). Cleavage of structural proteins during the assembly of the head of bacteriophage T4. nature, 227(5259), 680-685.

Lee, S. A., Bedford, M. R., \& Walk, C. L. (2018). Metaanalysis: explicit value of mono-component proteases in monogastric diets. Poultry science, 97(6), 2078-2085.

Magnúsdóttir, S., Heinken, A., Kutt, L., Ravcheev, D. A., Bauer, E., Noronha, A., ... \& Fleming, R. M. (2017). Generation of genome-scale metabolic reconstructions for 773 members of the human gut microbiota. Nature biotechnology, 35(1), 81.

Mahmood, T., Mirza, M. A., Nawaz, H., \& Shahid, M. (2018). Exogenous protease supplementation of poultry by-product meal-based diets for broilers: Effects on growth, carcass characteristics and nutrient digestibility. Journal of animal physiology and animal nutrition, 102(1), e233-e241.

Medvecky, M., Cejkova, D., Polansky, O., Karasova, D., Kubasova, T., Cizek, A., \& Rychlik, I. (2018). Whole genome sequencing and function prediction of 133 gut anaerobes isolated from chicken caecum in pure cultures. BMC genomics, 19(1), 561.

Mikhailova, E. O., Balaban, N. P., Mardanova, A. M., Rudakova, N. L., Ilyinskaya, O. N., Rudenskaya, G. N., ... \& Sharipova, M. R. (2009a). Purification of a subtilisin-like serine proteinase from recombinantBacillus subtilis during different phases of growth. Annals of microbiology, 59(2), 301-307.

Mikhailova, E. O., Mardanova, A. M., Balaban, N. P., Rudenskaya, G. N., Ilyinskaya, O. N., \& Sharipova, M. R. (2009b). Biochemical properties of Bacillus intermedius subtilisin-like proteinase secreted by a Bacillus subtilis recombinant strain in its stationary phase of growth. Biochemistry (Moscow), 74(3), 308-315.

Pelicia, K., Garcia, E., Móri, C., Faitarone, A. B. G., Silva, A. P., Molino, A. B., ... \& Berto, D. A. (2009). Calcium levels and limestone particle size in the diet of commercial layers at the end of the first production cycle. Brazilian Journal of Poultry Science, 11(2), 87-94.
Rao, D. E. C. S., Rao, K. V., Reddy, T. P., \& Reddy, V. D. (2009). Molecular characterization, physicochemical properties, known and potential applications of phytases: an overview. Critical reviews in biotechnology, 29(2), 182-198.

Sabirova, A. R., Rudakova, N. L., Balaban, N. P., Ilyinskaya, O. N., Demidyuk, I. V., Kostrov, S. V., ... \& Sharipova, M. R. (2010). A novel secreted metzincin metalloproteinase from Bacillus intermedius. FEBS letters, 584(21), 4419-4425.

Selle, P. H., \& Ravindran, V. (2007). Microbial phytase in poultry nutrition. Animal feed science and technology, 135(1-2), 1-41.

Siegert, W., Zuber, T., Sommerfeld, V., Krieg, J., Feuerstein, D., Kurrle, U., \& Rodehutscord, M. (2019). Prececal amino acid digestibility and phytate degradation in broiler chickens when using different oilseed meals, phytase and protease supplements in the feed. Poultry science, 98(11), 5700-5713.

Suleimanova, A. D., Toymentseva, A. A., Boulygina, E. A., Kazakov, S. V., Mardanova, A. M., Balaban, N. P., \& Sharipova, M. R. (2015a). High-quality draft genome sequence of a new phytase-producing microorganism Pantoea sp. 3.5. 1. Standards in genomic sciences, 10(1), 95 .

Suleimanova, A. D., Beinhauer, A., Valeeva, L. R., Chastukhina, I. B., Balaban, N. P., Shakirov, E. V., ... \& Sharipova, M. R. (2015b). Novel glucose-1phosphatase with high phytase activity and unusual metal ion activation from soil bacterium Pantoea sp. strain 3.5. 1. Applied and environmental microbiology, 81(19), 6790-6799.

Timbermont, L., Lanckriet, A., Dewulf, J., Nollet, N., Schwarzer, K., Haesebrouck, F., ... \& Van Immerseel, F. (2010). Control of Clostridium perfringens-induced necrotic enteritis in broilers by target-released butyric acid, fatty acids and essential oils. Avian Pathology, 39(2), 117-121.

Troshagina, D. S., Suleimanova, A. D., Itkina, D. L., \& Sharipova, M. R. (2018). Cloning of phytase genes from Pantoea sp. 3.5. 1 and Bacillus ginsengihumi M2. 11 in Pichia pastoris. BioNanoScience, 8(4), 1045-1053.

Vieira, B. S., Barbosa, S. A. P. V., Tavares, J. M. N., Beloli, I. G. C., de Melo Silva, G. M., Neto, H. R. L., ... \& Corrêa, G. D. S. S. (2016). Phytase and protease supplementation for laying hens in peak egg production. Semina: Ciências Agrárias, 37(6), 4285-4293.

Yao, M. Z., Zhang, Y. H., Lu, W. L., Hu, M. Q., Wang, W., \& Liang, A. H. (2012). Phytases: Crystal structures, protein engineering and potential biotechnological applications. Journal of Applied Microbiology, 112(1), 1-14. 
Yan, W., Sun, C., Yuan, J., \& Yang, N. (2017). Gut metagenomic analysis reveals prominent roles of Lactobacillus and cecal microbiota in chicken feed efficiency. Scientific reports, 7, 45308.
Yuan, L., Wang, M., Zhang, X., \& Wang, Z. (2017). Effects of protease and non-starch polysaccharide enzyme on performance, digestive function, activity and gene expression of endogenous enzyme of broilers. PLoS One, 12(3), e0173941.

\section{Appendix}

Table S1: Hematological parameters of young laying hens, \pm SD

\begin{tabular}{|c|c|c|c|}
\hline \multirow[b]{2}{*}{ Group } & \multicolumn{3}{|c|}{ Sampling time, day } \\
\hline & 30th & 60th & 90th \\
\hline \multicolumn{4}{|l|}{ Erythrocytes, $\cdot 10^{12} / \mathrm{L}$} \\
\hline Control & $1.78 \pm 0.03$ & $1.88 \pm 0.02$ & $1.84 \pm 0.03$ \\
\hline Proteinase group & $1.81 \pm 0.02$ & $1.95 \pm 0.05$ & $1.93 \pm 0.04$ \\
\hline Phytase group & $1.75 \pm 0.04$ & $1.91 \pm 0.01$ & $1.96 \pm 0.03$ \\
\hline \multicolumn{4}{|l|}{ Leucocytes, $\cdot 10^{9} / \mathrm{L}$} \\
\hline Control & $25.2 \pm 0.05$ & $27.9 \pm 0.07$ & $26.0 \pm 0.08$ \\
\hline Proteinase group & $26.3 \pm 0.04$ & $25.4 \pm 0.05$ & $27.8 \pm 0.06$ \\
\hline Phytase group & $26.1 \pm 0.06$ & $27.2 \pm 0.03$ & $26.5 \pm 0.04$ \\
\hline \multicolumn{4}{|l|}{ Hemoglobin, g/L } \\
\hline Control & $75.7 \pm 0.99$ & $71.0 \pm 0.67$ & $73.4 \pm 0.39$ \\
\hline Proteinase group & $80.0 \pm 1.01$ & $76.1 \pm 0.44$ & $75.3 \pm 0.70$ \\
\hline Phytase group & $77.8 \pm 0.65$ & $74.5 \pm 0.80$ & $76.0 \pm 0.41$ \\
\hline \multicolumn{4}{|l|}{ Hematocrit, $\%$} \\
\hline Control & $26.5 \pm 0.25$ & $25.8 \pm 0.26$ & $26.4 \pm 0.31$ \\
\hline Proteinase group & $25.5 \pm 0.33$ & $26.1 \pm 0.20$ & $27.3 \pm 0.15$ \\
\hline Phytase group & $26.8 \pm 0.18$ & $25.5 \pm 0.25$ & $26.2 \pm 0.31$ \\
\hline
\end{tabular}

Table S2: Biochemical blood parameters of birds, \pm SD

\begin{tabular}{|c|c|c|c|}
\hline \multirow[b]{2}{*}{ Group } & \multicolumn{3}{|c|}{ Sampling time, day } \\
\hline & 30th & 60th & 90th \\
\hline \multicolumn{4}{|l|}{ Total protein, $\mathrm{g} / \mathrm{L}$} \\
\hline Control & $34.8 \pm 1.7$ & $41.5 \pm 2.0$ & $49.4 \pm 1.5$ \\
\hline Proteinase group & $36.7 \pm 1.1$ & $44.2 \pm 1.6$ & $51.1 \pm 1.2$ \\
\hline Phytase group & $35.4 \pm 1.4$ & $42.9 \pm 0.9$ & $48.6 \pm 1.8$ \\
\hline \multicolumn{4}{|l|}{ Urea, $\mathrm{mmol} / \mathrm{L}$} \\
\hline Control & $2.53 \pm 0.05$ & $2.60 \pm 0.02$ & $2.40 \pm 0.07$ \\
\hline Proteinase group & $2.41 \pm 0.03$ & $2.52 \pm 0.06$ & $2.33 \pm 0.02$ \\
\hline Phytase group & $2.46 \pm 0.06$ & $2.64 \pm 0.04$ & $2.35 \pm 0.04$ \\
\hline \multicolumn{4}{|l|}{ Creatinine, $\mu \mathrm{mol} / \mathrm{L}$} \\
\hline Control & $30.4 \pm 1.4$ & $41.9 \pm 1.5$ & $44.0 \pm 0.8$ \\
\hline Proteinase group & $26.0 \pm 1.8$ & $39.2 \pm 1.2$ & $41.5 \pm 1.1$ \\
\hline Phytase group & $28.3 \pm 1.4$ & $40.5 \pm 1.3$ & $42.8 \pm 1.5$ \\
\hline \multicolumn{4}{|c|}{ Total calcium, mmol/L } \\
\hline Control & $2.05 \pm 0.04$ & $2.75 \pm 0.03$ & $5.08 \pm 0.05$ \\
\hline Proteinase group & $2.10 \pm 0.02$ & $2.80 \pm 0.05$ & $5.14 \pm 0.03$ \\
\hline Phytase group & $2.08 \pm 0.03$ & $2.78 \pm 0.02$ & $5.18 \pm 0.04$ \\
\hline \multicolumn{4}{|c|}{ Inorganic phosphorus, $\mathrm{mmol} / \mathrm{L}$} \\
\hline Control & $1.94 \pm 0.02$ & $2.15 \pm 0.03$ & $1.78 \pm 0.04$ \\
\hline Proteinase group & $2.01 \pm 0.01$ & $2.20 \pm 0.05$ & $1.85 \pm 0.02$ \\
\hline Phytase group & $2.18 \pm 0.03$ & $2.33 \pm 0.02$ & $1.93 \pm 0.04$ \\
\hline \multicolumn{4}{|c|}{ Aspartate aminotransferase, U/L } \\
\hline Control & $4.88 \pm 0.64$ & $3.45 \pm 0.80$ & $5.44 \pm 0.72$ \\
\hline Proteinase group & $5.05 \pm 0.55$ & $3.33 \pm 0.62$ & $4.90 \pm 0.48$ \\
\hline Phytase group & $5.73 \pm 0.39$ & $4.12 \pm 0.44$ & $5.02 \pm 0.53$ \\
\hline \multicolumn{4}{|c|}{ Alanine aminotransferase, U/L } \\
\hline Control & $11.7 \pm 0.91$ & $8.5 \pm 0.95$ & $10.4 \pm 0.77$ \\
\hline Proteinase group & $12.6 \pm 0.88$ & $9.0 \pm 0.79$ & $9.8 \pm 0.65$ \\
\hline Phytase group & $10.5 \pm 0.76$ & $8.2 \pm 0.61$ & $11.3 \pm 0.53$ \\
\hline
\end{tabular}




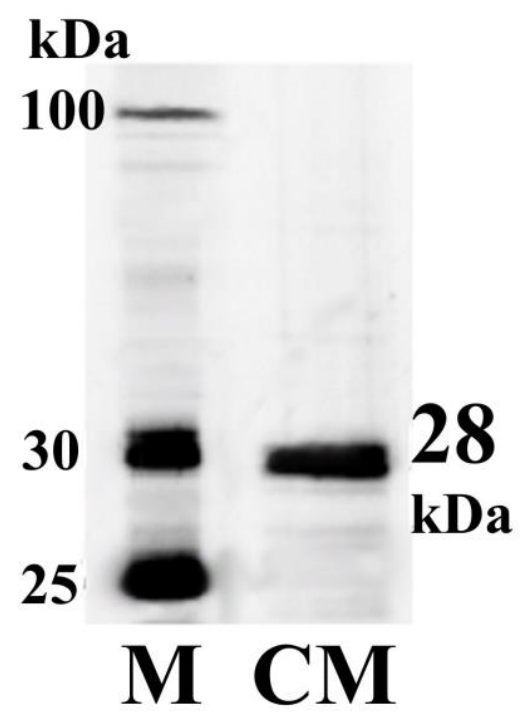

Fig. S1: SDS electrophoresis of B. pumilus proteinase fraction after carboxymethyl cellulose chromatography. M -protein ladder (\#2610, Thermo Scientific, USA)

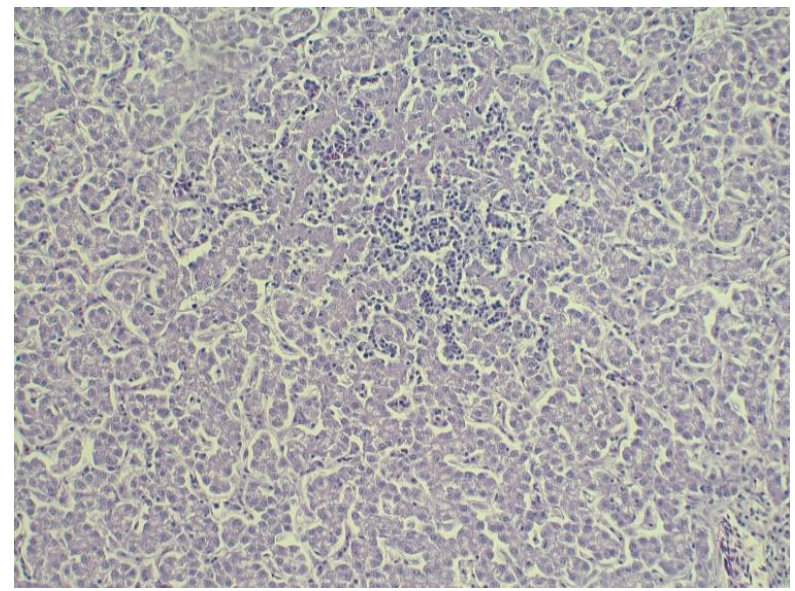

(A)

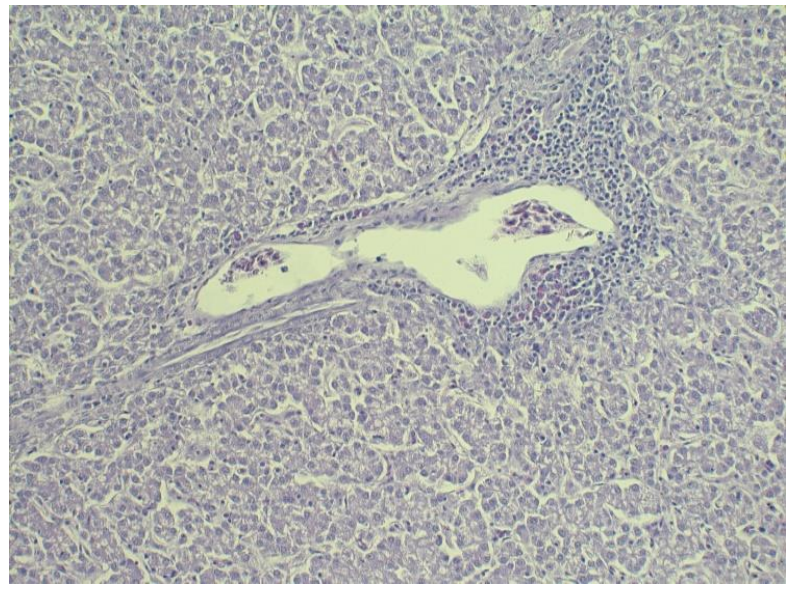

(B)

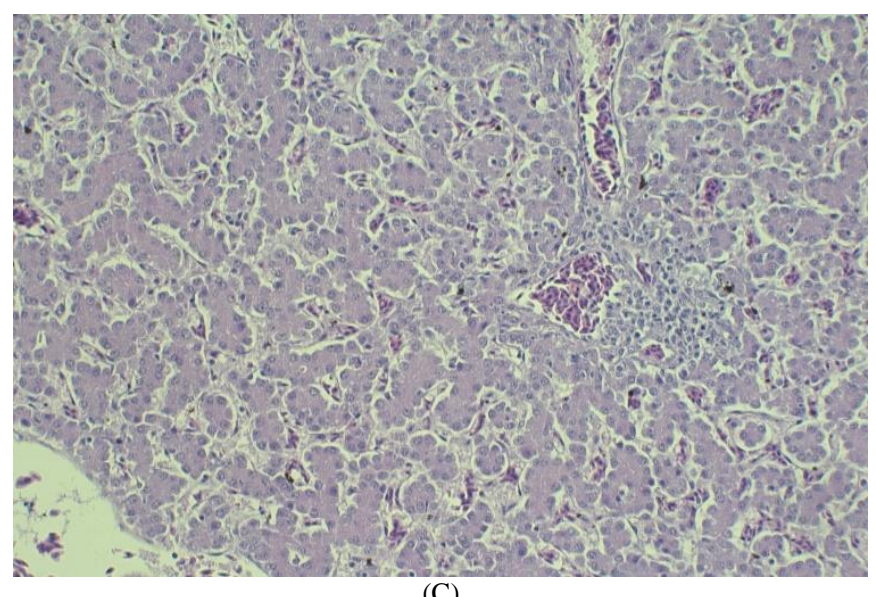

(C)

Fig. S2: Digital micrographs of liver tissues extracted from the control group (A), Proteinase group (B), Phytase group (C) (100x, Hematoxylin and eosin (H\&E) staining) 


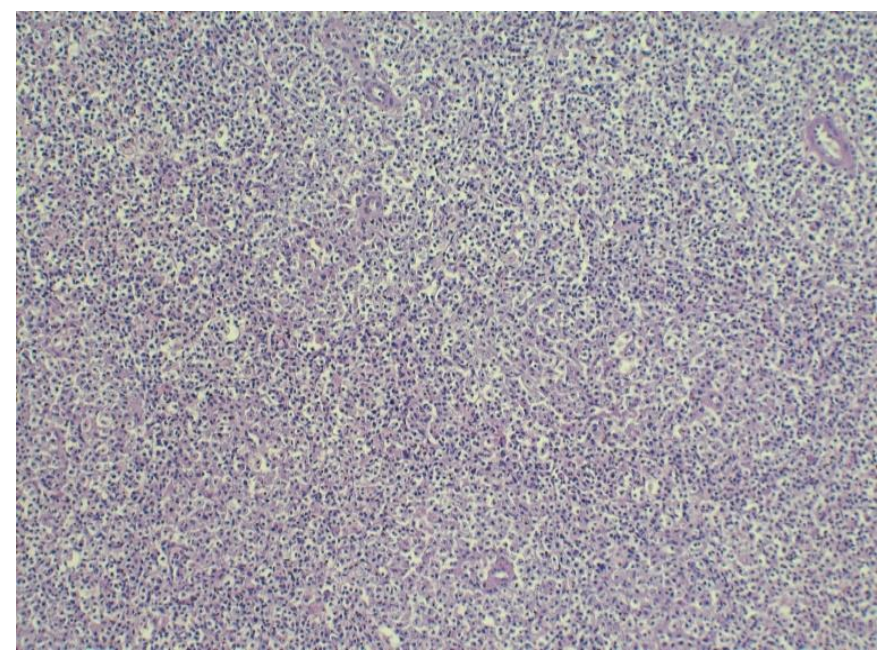

(A)

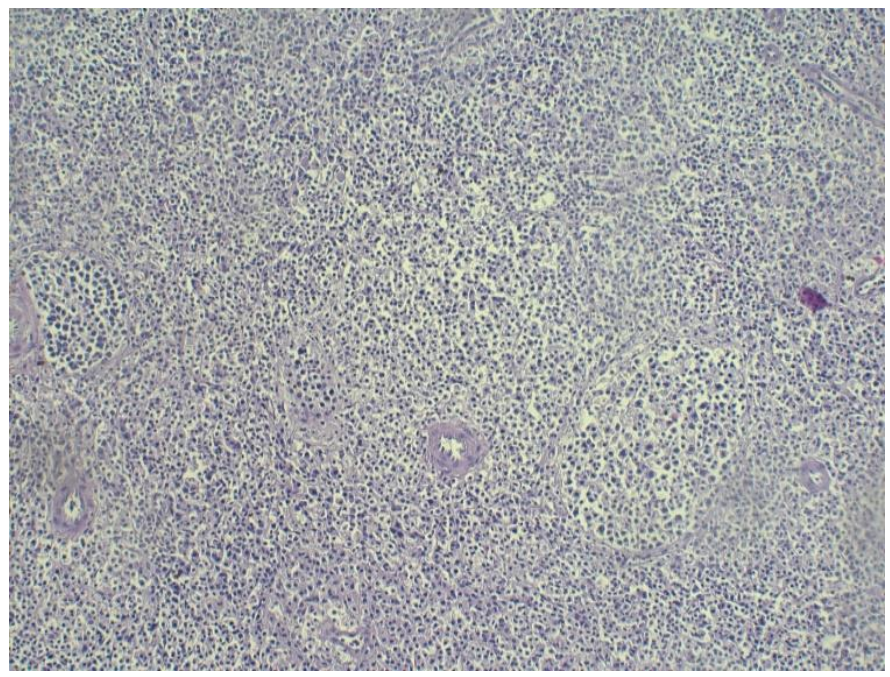

(B)

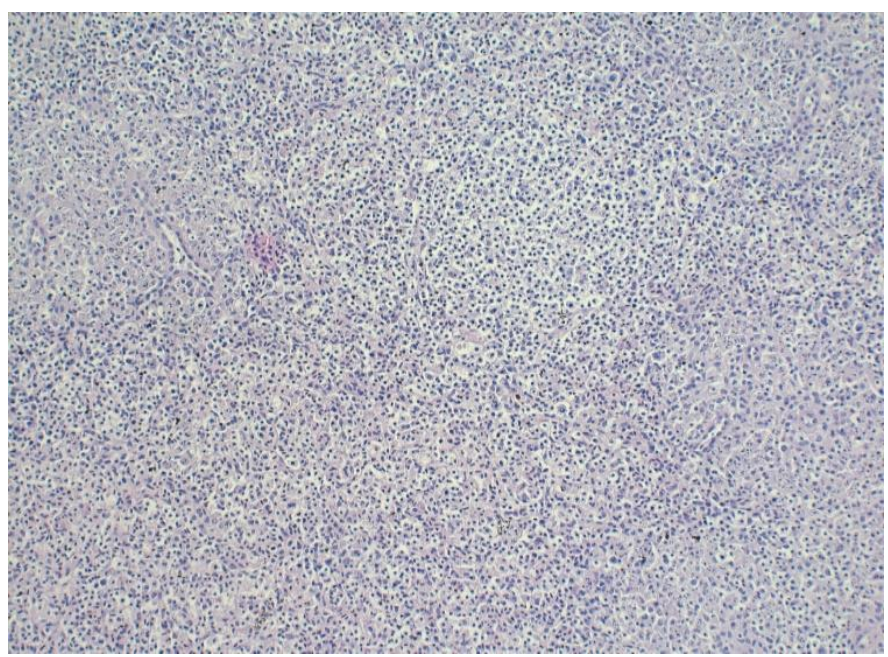

(C)

Fig. S3: Digital micrographs (100x) of H\&E stained segments of spleen harvested from birds of the Control group (A), Proteinase group (B), Phytase group (C) (100x, H\&E staining) 


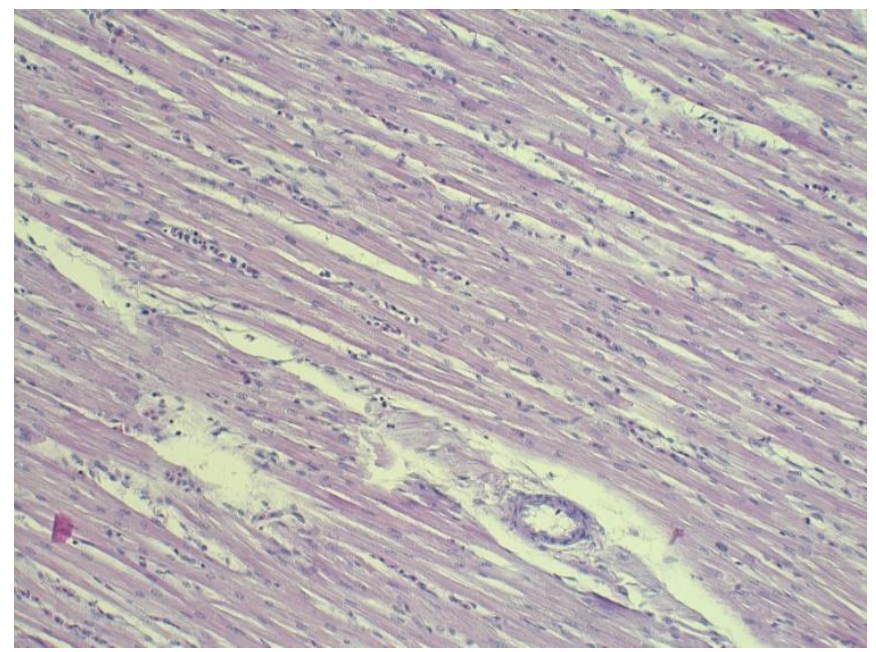

(A)

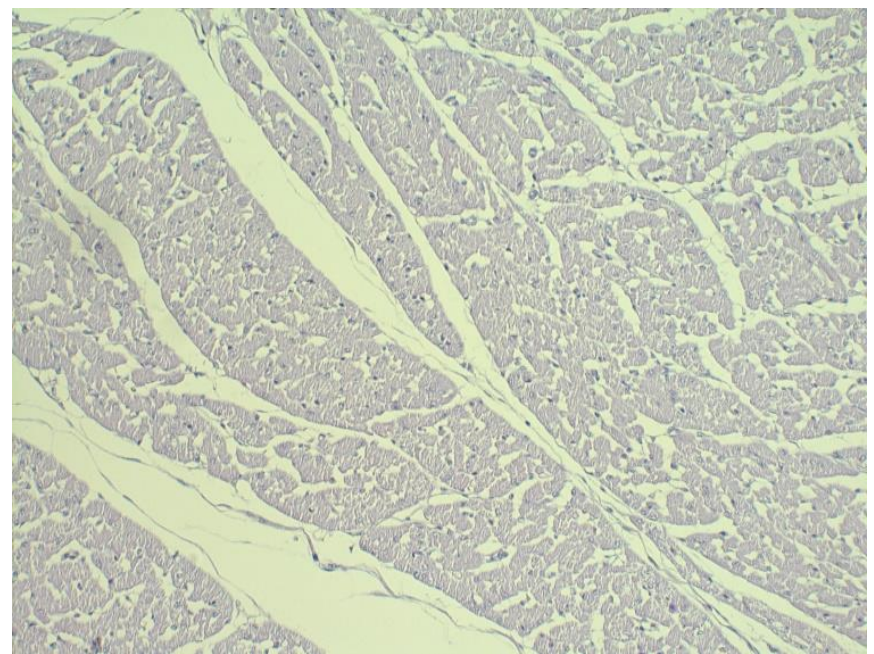

(B)

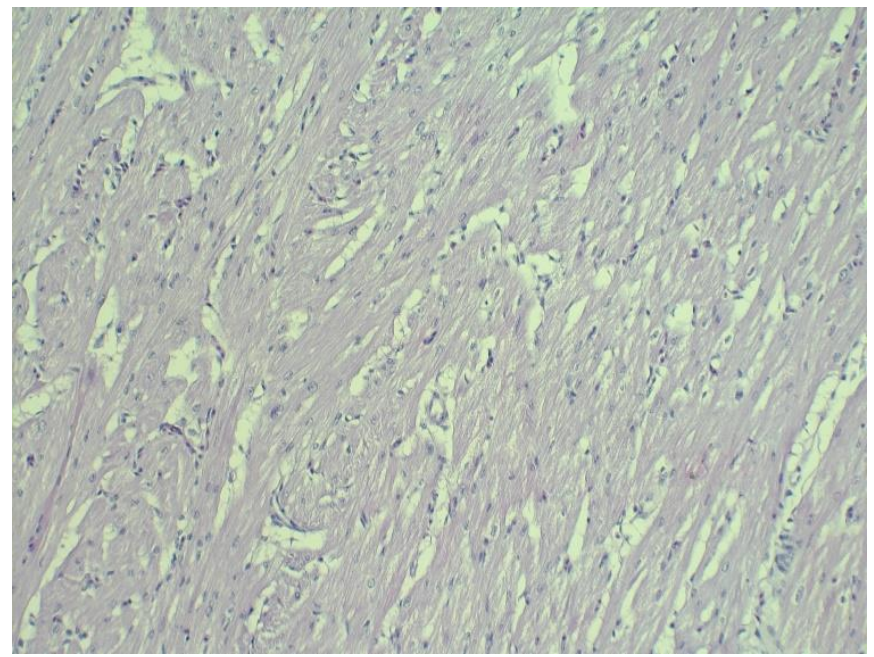

(C)

Fig. S4: Digital photographs of myocardium obtained from layer birds of the Control group (A), Proteinase group (B), Phytase group (C) $(100 x, H \& E$ staining) 